\title{
ENTREPRENEURIAL MINDSET DEVELOPMENT IN BUSINESS AND ENGINEERING EDUCATION - AN EXPERIMENT
}

\author{
N. Fain ${ }^{1, \otimes}$ and N. Vukašinović ${ }^{2}$ \\ ${ }^{1}$ Queen's University, Canada, ${ }^{2}$ University of Ljubljana, Slovenia \\ $\triangle$ nusa.fain@queensu.ca
}

\section{Abstract}

This paper presents an experimental comparative study into the entrepreneurial mindset of engineering and business students at a Canadian University. The study wants to test if the discipline has an effect on students perceptions of their entrepreneurial mindsets, when engaged in a similar educational approach. Key findings show that entrepreneurship can be taught and that there are differences in mindset change related to the discipline.

Keywords: entrepreneurship, design education, business models, commerce

\section{Introduction}

Due to technological advances, ease of access to the global marketplace and individual drive of today's generation $\mathrm{C}$ (always connected, communicating and clicking), small and medium size enterprises (SMEs), and start-ups in particular, have begun to drive the global economy (Le Merle and Davis, 2017). Entrepreneurship and developing business skills for the new era are on the rise, as the co-founders of new businesses need to develop the key skills to drive the success and growth of their companies.

Education seems to be catching up with the global trends, as entrepreneurship and enterprise education are being implemented into both business and engineering disciplines taught across the globe (Lackeus and Savetun, 2019).

The question though arises, if the approaches to teaching entrepreneurship across different disciplines deliver similar results and/or should they be tailored for different disciplines.

In this paper we report on an experiment we conducted within the commerce and engineering cohort at one of the Universities in Canada. Both cohorts were exposed to the same approach to teaching entrepreneurship and we tested whether their entrepreneurship mindset shift differed across the discipline or not. We wanted to test the following assumptions:

- Entrepreneurship can be taught in the same way and will yield similar results across disciplines, and

- Entrepreneurial mindset can be taught and will consequently help students navigate the job market better no matter the discipline they belong to.

We will first introduce the role of entrepreneurial mindset in developing a business and provide an overview of the relevant pedagogical approaches towards entrepreneurial education, before digging deeper into the disciplinary pedagogies relevant to engineering and business. We will then outline 
the experiment and the methodology used to test the entrepreneurial mindset across the two disciplines and present the key findings. Our contribution to the body of knowledge on enterprise education within engineering and business concludes this paper.

\section{Theoretical context}

To position the experiment appropriately, this paper will first look at the different pedagogical approaches to teaching business and engineering, and then look deeper into the key entrepreneurial mindset traits and their relevance within both disciplines.

\subsection{Engineering pedagogies}

There is a variety of skills that the engineers need to possess prior to entering the job market. The tacit knowledge related to how things work, how they can be build and what the relationships between constructs are seem to be key in developing a competent engineer (Zavbi and Vukasinovic, 2014). Next to the technical skills and engineering science that forms the backbone of engineering education, research has shown that engineers also need a variety of softer competences, including: (1) design capability, such as intelligence, imagination, creativeness, inventiveness, artfulness, technicality, pragmatism and productiveness, (2) design attitude, including the way of thinking about practical creativeness, motivation and inspiration of creating useful things, enjoyment of inventing artefacts and mind set related to materialization and realization, (3) design knowledge, gained through lectures, industrial case studies, projects and self-management, (4) design skills, such as multi-disciplinary cooperation, application of research and design methods, communication and exchange of technical information, analysis of complex design problems and task allocation, combining creative capacities with system development capacities, project management, and prototyping and testing, and (5) design experience, or the familiarity gained from seeing and doing things in the course of acting as a designer, and the obtained feelings and reflections related to designing and designs (van Doorn et al., 2008).

Project based learning has evolved as the dominant pedagogy to teach engineering design, as it is believed to offer both engineering science knowledge, as well as collaboration and team working skills (Zavbi and Vukasinovic, 2014; Dym et al., 2005). It presents an opportunity for students to gain the relevant engineering skills through interdisciplinary learning within a wider business or industry context. Mills and Treagust, (2003) suggest that this provides students with a wider understanding of the applicability of their engineering skills and knowledge.

\subsection{Business pedagogies}

Unlike engineering education, where engineering science plays a key role in developing the relevant skillset, business education often relies on developing the softer set of skills relevant within the business environment. Business pedagogies are often considered pedagogies of uncertainty, as the environment they teach about and for, is ever changing and continuously adapting to the new industrial/business trends. As defined by Shulman (2005) teaching and learning in business is characterized by the absence of routine in the discipline as such - it is an ever-changing practice, jumping from structured to creative approaches of doing things in extremely short periods of time, based predominantly on a critical review and analysis of what is happening in the business and social environment. Add technology to the mix and the before mentioned generation $\mathrm{C}$ is faced with continuous adaptation to the way they engage with their environments, which consequently influences how they approach learning and embracing their work environments as well (Le Merle and Davis, 2017).

Different approaches in practice and an ever-changing environment therefore demand different approaches in pedagogy. What the students need to learn, understand and acquire is not only the concepts relevant to the practice of business, but also the skills relevant to dealing with constant change in their social, political, technical and economic environments. The business, and in particular entrepreneurship discipline values insights generated from the variety of different paradigmatic positions to be found in the discipline (Shankar, 2009), and therefore students need to 
embrace and understand these positions to be able to become part of the communities of practice in their professional lives. At the same time, they are actively changing the discipline through their engagement with the digital world, where influencers are often the drivers of change and needs that generation $\mathrm{C}$ now exhibits.

\subsection{Entrepreneurial mindset}

Being entrepreneurial is positioned differently within disciplines. Popular belief has it that one cannot be taught how to be an entrepreneur and that one simply needs to be born with it. Research has disproved such myths, but there is still disagreement among academia what entrepreneurship education needs to be. Two schools of thought position the educational responsibility either at (1) teaching the students the process of starting up ventures, or (2) teaching them the mindset required to be entrepreneurial, such as creativity, teamwork and risk management (Lackeus and Savetun, 2019). As can be seen from the disciplinary discussion above, the second school of thought seems to apply both to engineering and business education. Engineers need to develop their designerly competences, including creativity, teamwork and problem solving (van Doorn et al., 2008). On the other hand, the business discipline is already based on the softer skills, acknowledged as relevant in developing an entrepreneurial mindset. For the purposes of this paper, we therefore define the entrepreneurial mindset in line with the second school of thought, basing the mindset on the development of key competences, such as creativity, problem-solving, risk mitigation and cooperation. We position the entrepreneurial mindset traits in line with Spinelli and Adams (2016) proposition, thus they include commitment and determination, courage, opportunity obsession, creativity and self-reliance, motivation to excel and leadership.

These traits enable entrepreneurs to identify opportunities, pursue them in terms of identifying the key customers and drive them to persevere, even when there are obstacles on the way. The traits also indicate that entrepreneurs are good leaders that are able to empathise and motivate their team to follow the overarching picture/vison they have proposed. Overall, being entrepreneurial means searching, seizing and exploiting opportunities developed, while mitigating risk through team engagement, courage and perseverance.

\section{The experiment}

To test the two key assumptions presented in the paper introduction, we have set up 'an experiment' to test the entrepreneurial mindset across the two disciplines. As outlined above, we followed Spinelli and Adams (2016)'s definition of the mindset that encompasses the following entrepreneurial traits:

a) Commitment and determination in terms of mission orientation, discipline, decisiveness, tenacity and persistence in solving problems;

b) Courage in terms of moral strength, fearless experimentation, tolerance of conflicts and failure and intense curiosity in the face of risk;

c) Opportunity obsession in terms of leadership in shaping the opportunity, knowledge of customer needs, market drive and value creation;

d) Tolerance to risk, ambiguity and uncertainty in terms of calculated risk, risk minimization and sharing, tolerance to lack of structure, stress and conflict and ability to integrate solutions;

e) Creativity, self-reliance and adaptability in terms of open-mindedness, restlessness with status quo, ability to adapt and no fear of failure;

f) Motivation to excel in terms of goal orientation, drive to achieve that is self-imposed, ability of support to others and a perspective and sense of humour;

g) Leadership in terms of being a self-starter, having internal locus of control, integrity and responsibility and being a team builder/hero maker, with patience.

These key traits of an entrepreneurial mindset were translated into a survey, where each of the mentioned traits was assessed on a 5-point Likert scale, where 1 indicates this trait was perceived as weak by the students and 5 was perceived as strong. The survey also asked the students to 
qualitatively discuss their key strengths and weaknesses in relation to the entrepreneurial mindset traits to give further depth to understanding where improvements can be made.

Commitment and determination were measured by assessing 6 mindset items, giving a total of 30 possible points for this trait. Courage was measured through 4 items, totalling 20 points. Opportunity obsession was also measured with 4 items, giving a total score of 20 . Tolerance of risk, ambiguity and uncertainty consisted of 6 items, giving possible scores of 30, followed by a 5-item measure of creativity, self-reliance and ability to adapt, which gave a total possible score of 25. A final two measures were motivation to excel, measured with 6-items and leadership measured with 5 items. Overall, a full mindset score can be summed to 180 points, indicating a $100 \%$ skillset relevant for an entrepreneurial mindset. The full survey is presented in the appendix of this paper.

The survey was administered at a Canadian University within two undergraduate entrepreneurship courses, tailored to the Commerce and Engineering students. The courses are taught by the same professor and cover the key components of launching a new venture. Although technically two different courses, they both take a very similar approach to introducing the students to the process of launching new ventures, with a particular focus on the marketing aspects of venture creation and launch. The full venture creation process is covered, outlining the key components of the business plan and the elements related to go-to market strategies relevant for new ventures. At the end of the semester, the students should have an in-depth understanding of how to perform effective market segmentation, create competitive value propositions for their target customers and build a go-to market strategy for their new ventures. The teaching approach is very much practice oriented - the students work on developing a business case and a go-to market strategy for their own business ideas/new ventures, based on the key learnings from the course. The delivery of the courses is a mixture of lectures, in-class work, case studies and visits from guest entrepreneurs. In 2018/19 academic year, 55 Commerce students and 80 Engineering students took the courses. All of the commerce students participated in both of the surveys, whereas 57 engineering students filled out the survey at the start of the course and 27 also filled it out after the course finished. We use all of the results to highlight the before and after traits, but we mapped the responses of only the 27 engineering students that filled both of the surveys to show the mindset change. The reasons for a smaller response rate from the engineering students may lie in the fact, that the survey was filed out in the first and last session of the course. The engineering students deal with their big capstone project at the same time and we assume that was prioritised against the evening entrepreneurship class. The survey was namely handed out in class, thus missing class would have resulted in not filling out either one of the surveys.

\section{Some key findings}

The purpose of the experiment was to establish if there are differences in perceived entrepreneurial mindset of engineering and commerce students. From Table 1 and Figure 1 it can be seen that the starting positions of Engineering and Commerce students seem rather equal.

Surprisingly, the engineering students seem to be extremely brave and have high levels of commitment, which is often a characteristic associated with business and management disciplines. Although commerce students perceive themselves as less brave, their motivation to excel, inherent to the discipline seems to be their key entrepreneurial driver. Figure 1 also indicates that the engineers already came to the course with some perceived notion of their entrepreneurial mindset. Product development (and R\&D in particular) seems to be the key driver of the engineers participating in the course. It may be due to their pedagogical approaches, where the drive to develop something revolutionary and/or radical is taught and emphasised throughout the curriculum or just the fact that they belong to the generation $\mathrm{C}$ that has already been born into the world where there is a need for continuous innovation and change (Le Merle and Davis, 2017). As one of the students emphasises in the qualitative response within the mindset survey: "the biggest strength I have as an engineer is the fact that I can develop and build things, now I need to learn, if I can turn it into a money making operation". 


\section{Entrepreneruial mindset before the course}

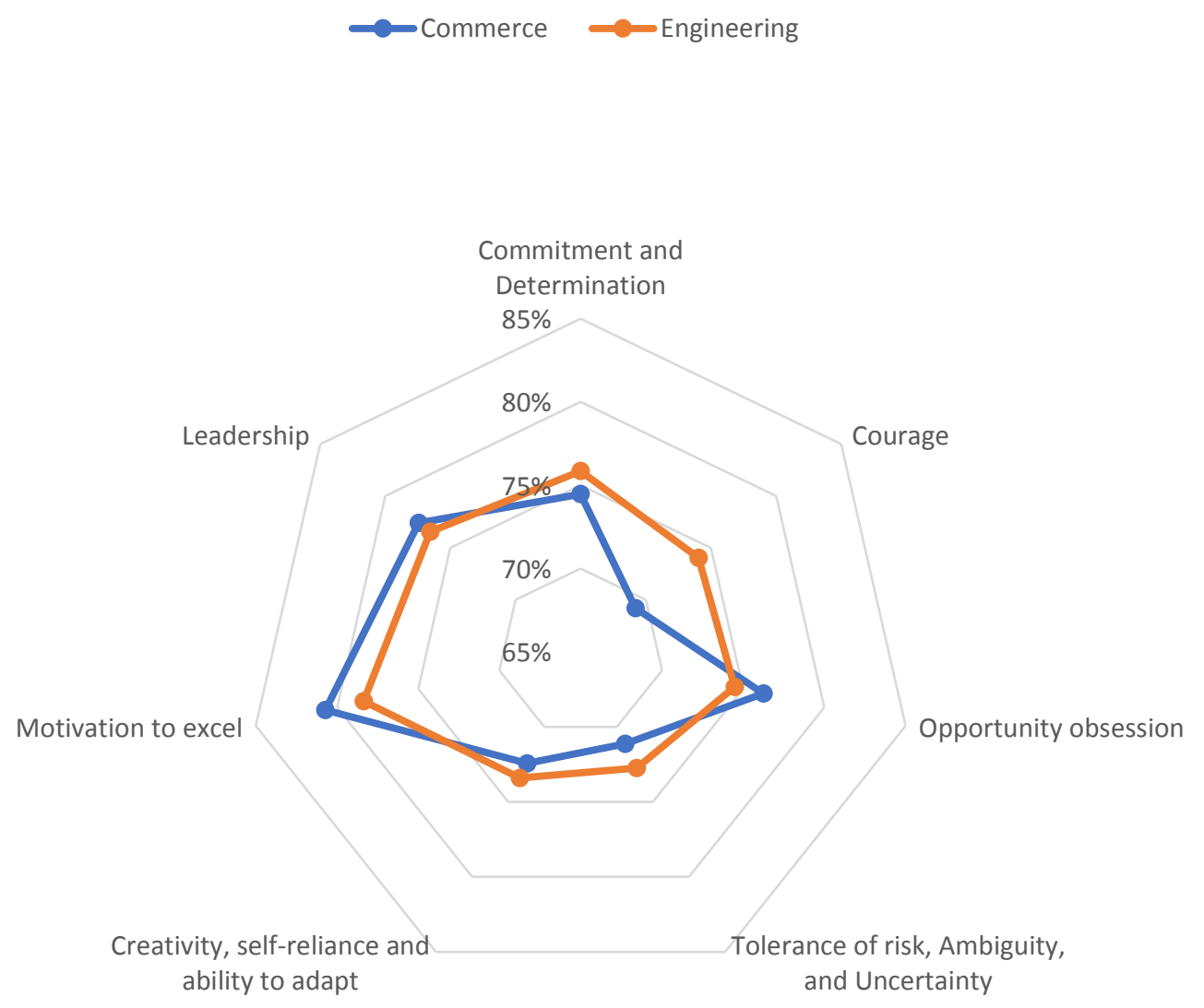

Figure 1. Entrepreneurial mindset as assessed by engineering and commerce student at the start of the course

Although the course seemed to have influenced both of the disciplines in terms of growth, engineers have noted a higher jump in their mindset from their business colleagues. An interesting notion presented in the spider diagram for the student mindset after the course (Figure 2) is that engineers seem to gain most within the opportunity obsession, motivation to excel and leadership traits. This indicates that they may have entered the course with some product/offering ideas, that they thought might not be feasible, but the course showed them processes and directions to make the ideas a reality, which has given the engineers confidence and knowledge how to proceed with the ideas into a viable business opportunity.

The magnitude of this mindset shift during and after the course is clearly visible from Figure 3 where all the investigated traits are normalised to a single parameter. This parameter was of the similar level at commerce and engineering students prior to the course, and both groups of students improved their mindset level. However, it is clear that the engineering students gained more from the course in terms of their mindsets.

There is another issue that can be extracted from the results above, and can be noticed with both commerce and engineering students, before and even after the course: the courage, more specifically the fear of failure is and remains the greatest inhibitor of entrepreneurial mindset. The fear of failure was the weakest point in all four surveys (before and after, commerce and engineering students), and obviously needs to be carefully addressed in the future. 
Table 1. Entrepreneurial mindset traits across the two disciplines

\begin{tabular}{|c|c|c|c|c|c|c|c|c|c|c|c|c|}
\hline \multirow{2}{*}{ Commitment and Determination } & \multicolumn{3}{|c|}{$\begin{array}{l}\text { Commerce } \\
\mathrm{N}=55 \text { before }\end{array}$} & \multicolumn{3}{|c|}{$\begin{array}{l}\text { Commerce } \\
\mathrm{N}=55 \text { after }\end{array}$} & \multicolumn{3}{|c|}{$\begin{array}{l}\text { Engineering } \\
\mathrm{N}=57 \text { before }\end{array}$} & \multicolumn{3}{|c|}{$\begin{array}{l}\text { Engineering } \\
\mathrm{N}=27 \text { after }\end{array}$} \\
\hline & average & st dev & $\%$ & average & st.dev & $\%$ & average & st dev & $\%$ & average & st dev & $\%$ \\
\hline Decisiveness & 3.5 & 0.8 & $70 \%$ & 3.8 & 0.8 & $76 \%$ & 3.4 & 0.9 & $68 \%$ & 4.0 & 0.8 & $79 \%$ \\
\hline Tenacity & 3.8 & 0.8 & $75 \%$ & 4.0 & 0.8 & $79 \%$ & 3.9 & 0.7 & $78 \%$ & 4.1 & 0.7 & $82 \%$ \\
\hline Discipline & 3.8 & 0.8 & $76 \%$ & 3.9 & 0.7 & $79 \%$ & 3.9 & 0.7 & $79 \%$ & 4.0 & 1.0 & $80 \%$ \\
\hline Persistence in solving problems & 4.2 & 0.8 & $83 \%$ & 4.1 & 0.7 & $82 \%$ & 4.1 & 0.8 & $82 \%$ & 4.3 & 0.9 & $87 \%$ \\
\hline Willingness to sacrifice & 3.4 & 1.1 & $69 \%$ & 3.7 & 0.8 & $75 \%$ & 3.7 & 0.9 & $73 \%$ & 3.9 & 1.2 & $77 \%$ \\
\hline \multirow[t]{2}{*}{ Total immersion in the mission } & 3.8 & 0.9 & $75 \%$ & 3.9 & 0.8 & $79 \%$ & 3.9 & 0.7 & $79 \%$ & 4.2 & 0.9 & $83 \%$ \\
\hline & 22.3 & 3.0 & $74 \%$ & 23.2 & 3.4 & $77 \%$ & 22.8 & 2.7 & $76 \%$ & 24.3 & 4.3 & $81 \%$ \\
\hline \multicolumn{13}{|l|}{ Courage } \\
\hline Moral strength & 4.2 & 0.7 & $84 \%$ & 4.3 & 0.7 & $86 \%$ & 4.2 & 0.7 & $83 \%$ & 4.3 & 0.8 & $85 \%$ \\
\hline Fearless experimentation & 3.3 & 1.1 & $65 \%$ & 3.4 & 1.0 & $69 \%$ & 3.7 & 0.9 & $74 \%$ & 3.8 & 0.8 & $76 \%$ \\
\hline Unafraid of conflicts, failure & 3.0 & 1.1 & $59 \%$ & 3.4 & 1.1 & $67 \%$ & 3.4 & 1.0 & $68 \%$ & 3.7 & 1.1 & $73 \%$ \\
\hline \multirow{2}{*}{ Intense curiosity in the face of risk } & 3.4 & 1.1 & $69 \%$ & 3.4 & 1.1 & $68 \%$ & 3.5 & 0.9 & $71 \%$ & 4.1 & 0.9 & $83 \%$ \\
\hline & 13.8 & 3.0 & $69 \%$ & 14.5 & 3.0 & $72 \%$ & 14.8 & 2.7 & $74 \%$ & 15.9 & 2.8 & $79 \%$ \\
\hline \multicolumn{13}{|l|}{ Opportunity obsession } \\
\hline $\begin{array}{l}\text { Leadership in shaping the } \\
\text { opportunity }\end{array}$ & 4.0 & 0.9 & $80 \%$ & 4.1 & 0.8 & $82 \%$ & 3.6 & 0.9 & $72 \%$ & 4.3 & 1.0 & $86 \%$ \\
\hline $\begin{array}{l}\text { Having knowledge of customer } \\
\text { needs }\end{array}$ & 3.9 & 0.7 & $79 \%$ & 4.0 & 0.8 & $80 \%$ & 3.8 & 1.0 & $75 \%$ & 4.1 & 0.8 & $83 \%$ \\
\hline Being market driven & 3.7 & 0.9 & $73 \%$ & 3.9 & 0.9 & $77 \%$ & 3.6 & 1.0 & $73 \%$ & 3.9 & 1.0 & $78 \%$ \\
\hline \multirow[t]{2}{*}{ Obsession with value creation } & 3.7 & 1.0 & $74 \%$ & 3.9 & 1.0 & $77 \%$ & 3.9 & 1.0 & $78 \%$ & 4.1 & 1.1 & $82 \%$ \\
\hline & 15.3 & 2.4 & $76 \%$ & 15.6 & 3.3 & $78 \%$ & 14.9 & 3.0 & $74 \%$ & 16.4 & 3.4 & $82 \%$ \\
\hline \multicolumn{13}{|l|}{$\begin{array}{l}\text { Tolerance of risk, Ambiguity, } \\
\text { and Uncertainty }\end{array}$} \\
\hline Calculated risk taker & 3.9 & 1.0 & $77 \%$ & 3.9 & 0.8 & $78 \%$ & 3.8 & 0.8 & $77 \%$ & 4.2 & 0.9 & $84 \%$ \\
\hline Risk minimizer & 3.6 & 1.1 & $72 \%$ & 3.9 & 0.9 & $77 \%$ & 3.7 & 1.0 & $75 \%$ & 4.1 & 1.1 & $83 \%$ \\
\hline Risk sharer & 3.4 & 0.9 & $69 \%$ & 3.6 & 0.8 & $72 \%$ & 3.4 & 0.8 & $69 \%$ & 3.7 & 1.0 & $74 \%$ \\
\hline $\begin{array}{l}\text { Tolerance of uncertainty and lack } \\
\text { of structure }\end{array}$ & 2.9 & 1.2 & $58 \%$ & 3.1 & 1.1 & $61 \%$ & 3.2 & 1.0 & $65 \%$ & 3.6 & 1.0 & $73 \%$ \\
\hline Tolerance of stress and conflict & 3.5 & 1.1 & $70 \%$ & 3.6 & 1.0 & $73 \%$ & 3.5 & 0.9 & $71 \%$ & 3.9 & 1.1 & $77 \%$ \\
\hline \multirow{2}{*}{$\begin{array}{l}\text { Resolve problems/integrate } \\
\text { solutions }\end{array}$} & \begin{tabular}{|l|}
4.1 \\
\end{tabular} & 0.7 & $83 \%$ & \begin{tabular}{|l|}
4.0 \\
\end{tabular} & 0.6 & $80 \%$ & 4.1 & 0.8 & $81 \%$ & 4.3 & 0.7 & $87 \%$ \\
\hline & 21.3 & 3.2 & $71 \%$ & 22.1 & 3.0 & $74 \%$ & 21.8 & 3.1 & $73 \%$ & 23.9 & 3.3 & $80 \%$ \\
\hline \multicolumn{13}{|l|}{$\begin{array}{l}\text { Creativity, self-reliance and } \\
\text { ability to adapt }\end{array}$} \\
\hline Open-minded, lateral thinker & 4.1 & 0.8 & $81 \%$ & 4.0 & 1.0 & $80 \%$ & 3.9 & 0.9 & $77 \%$ & 4.1 & 0.9 & $83 \%$ \\
\hline Restles & 3.4 & 0.9 & $68 \%$ & 3.5 & 1.0 & $69 \%$ & 3.6 & 0.9 & $72 \%$ & 3.9 & 0.9 & $77 \%$ \\
\hline Ability to adapt & 4.3 & 0.7 & $85 \%$ & 4.3 & 0.6 & $87 \%$ & 4.2 & 0.8 & $84 \%$ & 4.5 & 0.8 & $90 \%$ \\
\hline Lack of fear of failure & 2.9 & 1.2 & $58 \%$ & 3.1 & 1.1 & $61 \%$ & 3.1 & 1.0 & $62 \%$ & 3.5 & 1.3 & $70 \%$ \\
\hline \multirow{2}{*}{$\begin{array}{l}\text { Ability to conceptualize/sweat } \\
\text { details }\end{array}$} & 3.5 & 1.0 & $70 \%$ & 3.7 & 0.7 & $74 \%$ & 3.6 & 0.9 & $72 \%$ & 4.0 & 0.7 & $80 \%$ \\
\hline & 18.1 & 3.2 & $72 \%$ & 18.5 & 3.1 & $74 \%$ & 18.4 & 3.2 & $73 \%$ & 20.0 & 3.4 & $80 \%$ \\
\hline \multicolumn{13}{|l|}{ Motivation to excel } \\
\hline Goal and results orientation & 4.4 & 0.8 & $87 \%$ & 4.5 & 0.7 & $89 \%$ & 4.2 & 0.8 & $84 \%$ & 4.5 & 0.6 & $90 \%$ \\
\hline Self-imposed drive to achieve/grow & 4.4 & 0.7 & $89 \%$ & 4.2 & 0.9 & $84 \%$ & 4.2 & 0.8 & $84 \%$ & 4.3 & 0.7 & $87 \%$ \\
\hline Low need for status and power & 3.1 & 1.1 & $63 \%$ & 3.6 & 1.0 & $71 \%$ & 3.4 & 1.0 & $67 \%$ & 3.5 & 1.0 & $70 \%$ \\
\hline Inter-personally supporting & 3.9 & 0.9 & $78 \%$ & 3.8 & 0.8 & $76 \%$ & 3.8 & 0.9 & $76 \%$ & 4.2 & 0.9 & $84 \%$ \\
\hline Awareness of weaknesses & 4.1 & 0.7 & $83 \%$ & 4.1 & 0.7 & $82 \%$ & 3.8 & 0.9 & $76 \%$ & 4.3 & 1.0 & $86 \%$ \\
\hline \multirow{2}{*}{$\begin{array}{l}\text { Having perspective and sense of } \\
\text { humor }\end{array}$} & 4.4 & 0.6 & $88 \%$ & 4.4 & 0.8 & $87 \%$ & 4.2 & 0.8 & $85 \%$ & 4.6 & 0.6 & $91 \%$ \\
\hline & 24.2 & 2.7 & $81 \%$ & 24.4 & 2.9 & $81 \%$ & 23.5 & 2.8 & $78 \%$ & 25.4 & 2.7 & $85 \%$ \\
\hline \multicolumn{13}{|l|}{ Leadership } \\
\hline elf-start & 3.6 & 1.0 & $72 \%$ & 3.8 & 1.1 & $76 \%$ & 3.7 & 1.0 & $74 \%$ & 4.1 & 1.1 & $81 \%$ \\
\hline Having internal locus of control & 3.8 & 1.0 & $75 \%$ & 3.7 & 1.0 & $75 \%$ & 3.8 & 0.7 & $76 \%$ & 4.0 & 0.8 & $81 \%$ \\
\hline Having integrity and reliability & 4.3 & 0.6 & $85 \%$ & 4.3 & 0.8 & $87 \%$ & 4.2 & 0.8 & $83 \%$ & 4.5 & 0.8 & $90 \%$ \\
\hline Having patience & 3.8 & 1.0 & $77 \%$ & 4.0 & 1.0 & $79 \%$ & 3.8 & 0.9 & $76 \%$ & 4.1 & 1.0 & $81 \%$ \\
\hline Being a team builder and hero & 3.9 & 0.8 & $78 \%$ & 4.0 & 0.9 & $80 \%$ & 3.7 & 0.8 & $74 \%$ & 4.0 & 0.8 & $81 \%$ \\
\hline & 19.4 & 2.9 & $77 \%$ & \begin{tabular}{|l|}
19.9 \\
\end{tabular} & 2.9 & $79 \%$ & \begin{tabular}{|l|}
19.1 \\
\end{tabular} & 3.0 & \begin{tabular}{|l|}
$77 \%$ \\
\end{tabular} & 20.7 & 3.2 & $83 \%$ \\
\hline
\end{tabular}




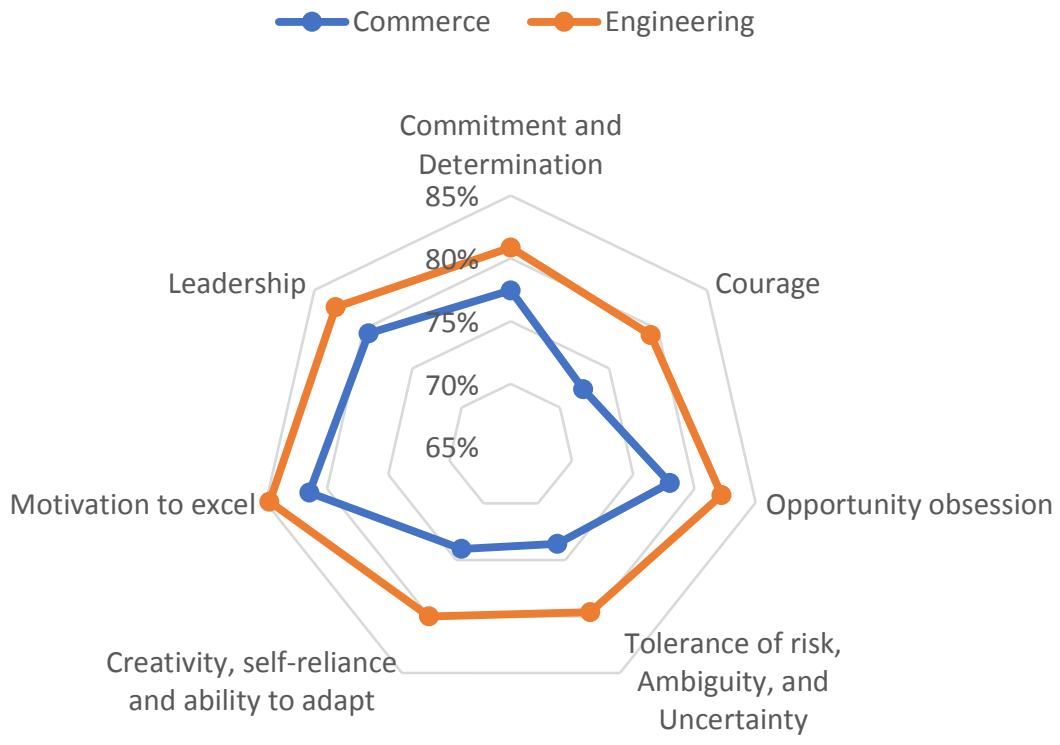

Figure 2. Entrepreneurial mindset of engineering and commerce students at the end of the course

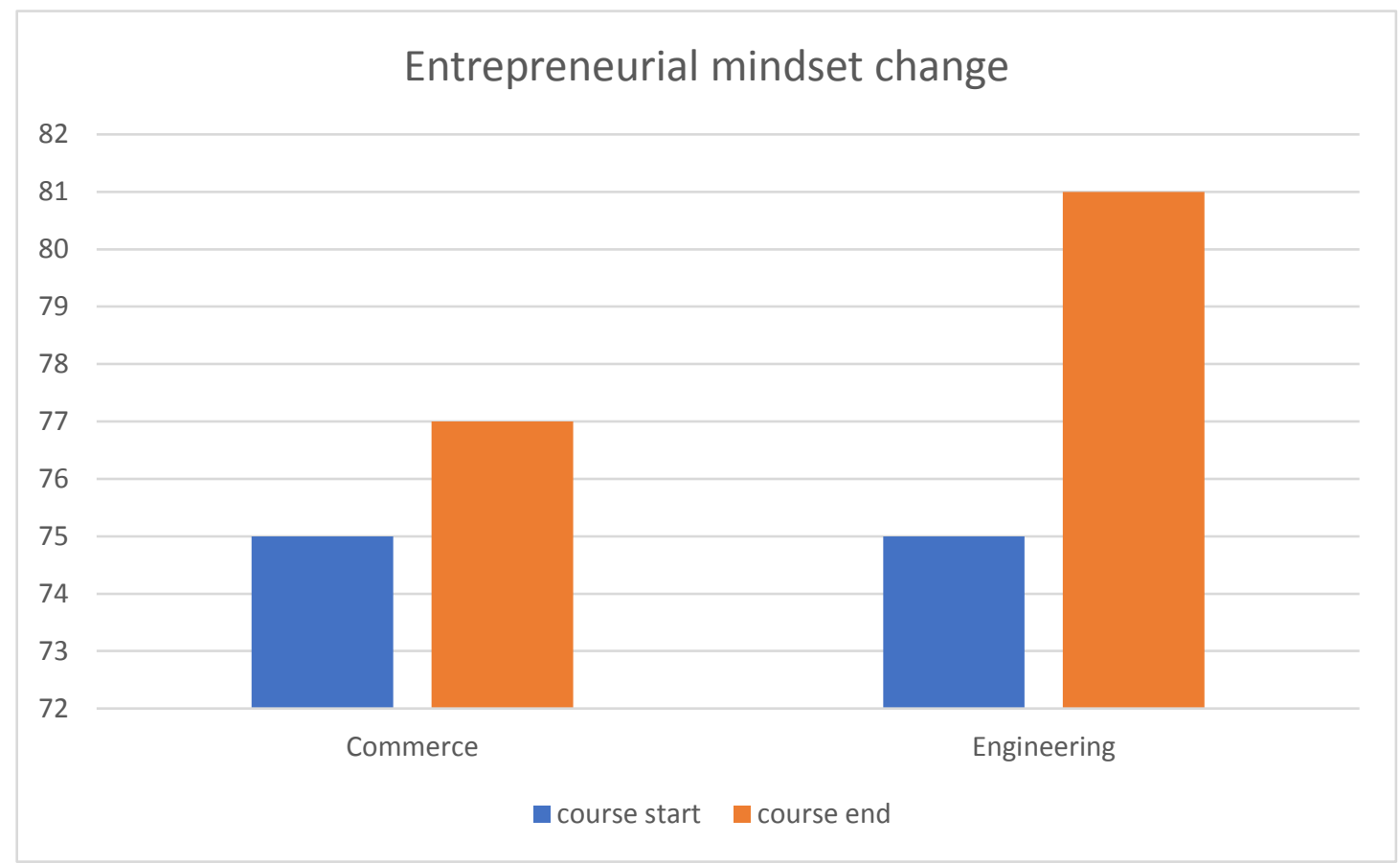

Figure 3. Entrepreneurial mindset change - disciplines compared

\section{Conclusion}

Entrepreneurship seems to be a skillset and a mindset that today's workforce needs to poses in order to succeed in the ever-changing industrial/work environment. Education, no matter the discipline, seems to be playing catch-up in providing the students with this required skillset. Entrepreneurship education within a Canadian University was put through an experiment, to assess, if the disciplinary background 
of the students influences how they perceive themselves in terms of being entrepreneurial. Engineering and commerce students participating in a venture creation course assessed their entrepreneurial mindset at the start and at the end of their course. We wanted to assess, if they can be taught entrepreneurship, and if discipline matters at all.

We started with the assumption that the business students will assess themselves better than the engineering ones, as their discipline is one of uncertainty, where softer skills are taught from the start and represent the core of the discipline. The experiment disproved that assumption, as engineers assessed themselves higher or at the same level before and after the course. Based on this we postulate two propositions:

1. Entrepreneurial mindset can be taught and improved with educational approaches that are project-based and put the students into real life venture situations.

2. There seems to be a minor disciplinary influence, as the mindset improved more with engineering students than it did with the commerce ones.

In the future, we need to investigate further what factors are main motivators to increase the entrepreneurial mindset of the students of various disciplines and how to increase their courage to start a new business. Furthermore, we plan to expand this research to other countries and disciplines to see if these results are also country dependant.

There is a variety of limitations to this experiment, including the lack of control to all the other influences on the mindset of students. We assumed the course only influenced the change in mindset. The purpose of the paper was not to assess the pedagogical approach, but to see if the discipline as such matters at all. The experiment presents a starting point in our larger study of entrepreneurial mindsets, with which we hope to discover what key traits are inherent to the discipline and which ones need to be prioritised when teaching entrepreneurship to different disciplines.

\section{References}

Dym, C. et al. (2005), "Engineering Design Thinking, Teaching, and Learning", Journal of Engineering Education, Vol. 94 No. 1, pp. 103-120.

Lackeus, M. and Savetun, K. (2019), “Assessing the impact of enterprise education in three leading swedish compulsory schools", Journal of Small Business Managmenet, pp. 33-59.

Le Merle, M.C. and Davis, A. (2017), Corporate innovation in the fifth era, Cartwright Publishing, Corte Madera, California.

Mills, J. and Treagust, D. (2003), "Engineering education-Is problem-based or project-based learning the answer?", Australasian Journal of Engineering Education, Vol. 3 No. 2, pp. 2-16.

Shankar, A. (2009), "Reframing critical marketing", Journal of marketing management, Vol. 25 No. 7-8, pp. 681-696.

Shulman, L. (2005), "Pedagogies of Uncertainty", Liberal Education, Vol. 91 No. 2. http://www.aacu.org/ liberaleducation/le-sp05/le-sp05feature2.cfm

Spinelli Jr., S. and Adams Jr., R. (2016), New venture creation: Entrepreneurship for the 21st Century (Tenth Edition ed.), McGraw-Hill Education, New York.

van Doorn, E., Moes, N. and Fain, N. (2008), “Attitude development in designer's education”, Proceedings of the TMCE 2008.

Zavbi, R. and Vukasinovic, N. (2014), “A concept of academia-industry collaboration to facilitate the building of technical and professional competencies in new product development", International journal of engineering education, Vol. 30 No. 6, pp. 1562-1578. 